Teresa $\mathrm{Boi}^{*}$

ORCID: 0000-0002-7992-2547

Sassari, Włochy

\title{
Pedagogika w dialogu: badania, zastosowanie i perspektywy, Słowenia, Škofja Loka, 14-17 czerwca 2018 r.
}

Seminarium naukowe „Pedagogika w dialogu” to kolejny etap procesu badawczego międzynarodowej sieci naukowej Inondacja Edukacja dla Jedności (Educazione di Unità - EdU) ${ }^{1}$, prowadzonego w celu zbadania, promo-

* Teresa Boi, metodyk, nauczycielka, doktorantka w Instytucie Uniwersyteckim Sophia (Istituto Universitario Sophia) w Loppiano we Włoszech. Członek Centrum Badań Interdyscyplinarnych Szkoły Abbà Ruchu Focolari (Centro di studi interdisciplinari Scuola Abbà del Movimento dei Focolari). Koordynator Międzynarodowej Komisji Edukacji dla Jedności (EdU). Adres: Via Piave, 15, 00046 Grottaferrata (Rm) Italia; e-mail: pedagogia@focolare.org.

${ }^{1}$ Inondacja Pedagogia Educazione-Unità (EdU) to sieć specjalistów w zakresie wychowania i kształcenia zajmująca się promowaniem refleksji i prac badawczych mających na celu opracowanie teorii wychowania opartej na duchowości komunii Chiary Lubich. Duchowość komunii od samego początku przynosiła odnowę nie tylko duchową, lecz także społeczną i kulturową. Świadczą o tym liczne dzieła społeczne i tytuł doktora honoris causa przyznany Chiarze Lubich w wielu dyscyplinach naukowych. Powstanie EdU związane jest z doktoratem honoris causa z pedagogiki nadanym jej przez Catholic University of America w Waszyngtonie 10 listopada 2000 r. Przy tej okazji Lubich stwierdziła, że Ruch i jego historia mogą być widziane jako wielkie i niezwykłe wydarzenie wychowawcze, które zawiera wszystkie elementy wychowania, a także teorię wychowania, która stanowi podstawę działania wychowawczego. EdU może być zatem zdefiniowane jako międzynarodowe laboratorium, którego zadaniem jest zgłębianie podstaw wychowania będących owocem myśli i doświadczenia duchowego Chiary Lubich i Ruchu Focolari. Dokonuje się to w dialogu ze współczesną myślą na temat 
wania i rozpowszechniania różnych doświadczeń edukacyjnych pedagogii komunii $^{2}$ z kilku miejsc południowo-wschodniej Europy. Tematyka dialogu - jako podstawowego wymiaru doświadczenia edukacyjnego w kontestach wieloetnicznych, wielokulturowych, międzyreligijnych i zglobalizowanych - została pogłębiona w perspektywie badań partycypacyjnych oraz wiedzy doświadczalnej przez 90 uczestników, pochodzących z Chorwacji, Francji, Hiszpanii, Macedonii, Serbii, Słowenii i Włoch, a także innych, biorących udział w spotkaniu za pośrednictwem Internetu. W seminarium uczestniczyli nauczyciele, także akademiccy, wychowawcy, naukowcy, studenci i doktoranci.

Seminarium, charakteryzujące się partycypacyjnym podejściem do badań, miało na celu ukazanie związku pomiędzy wiedzą teoretyczną - produktem badaczy naukowych, a wiedzą doświadczalną - owocem codziennej praktyki nauczycieli, wychowawców i pracowników. Była to okazja do wymiany refleksji nad metodami, celami i rezultatami kształcenia.

Szkoła jest przede wszystkim wspólnotą praktyk edukacyjnych. Nauczanie jest działaniem performatywnym, które realizuje się w różnych formach: podczas wyjaśniania, przydzielania zadań, dokonywania oceny, ćwiczenia woli i ukonkretniania własnych idei. Są to działania, które mogą być przedmiotem refleksji, mogą być opowiedziane i podarowane innym, aby umożliwić odtworzenie ich w innych kontekstach. W tym celu naukowcy przygotowali dla tego procesu badawczego wytyczne, które przesłali do szkół, aby nauczyciele i inni pracownicy mieli użyteczne narzędzia do zbadania sytuacji, w której działają, do przeanalizowania jej, a następnie właściwego odczytania jej dynamiki i odniesień.

W pierwszym dniu seminarium uczestnicy zapoznali się z rzeczywistością Przedszkola „Promień Słońca” (Soncni zarek), które znajduje się w słoweńskim miasteczku Stara Loka. Była to okazja do podzielenia się doświadczeniami zdobytymi podczas działalności dydaktycznej prowadzonej w grupach przedszkolnych oraz poznania zawodowych i życiowych historii pracowników tej instytucji. Uczęszcza do niej ponad 100 dzieci podzielonych na trzy oddziały żłobka i trzy oddziały przedszkola (od 3 do 6 lat).

wychowania, poprzez wymianę refleksji nad metodami, celami i rezultatami edukacyjnymi, co jest prezentowane podczas kongresów, seminariów i konferencji w różnych częściach świata.

2 Określenie ,pedagogia komunii” jest stosowane głównie w kręgach języka włoskiego oraz w krajach bałkańskich dla zdefiniowania tego wszystkiego, co obejmuje szeroko pojętą pedagogię Chiary Lubich [przypis thumacza]. 
Ta placówka wychowawcza powstała w 2003 r. z pragnienia i pasji kształcenia „nowych” osób o sercu i umyśle otwartym na najbliższych i na cały świat, a działo się to w takim historycznym kontekście, gdy słowa takie jak: edukacja, miłość, rodzina i wartości były całkowicie wyłączone z programów edukacyjnych. W centrum działań wychowawczych tego przedszkola stawia się dziecko-osobę i jego podstawową potrzebę bycia szanowanym i uznanym jako jedyna i niepowtarzana istota, dar dla innych bez względu na różnice. W programie edukacyjnym uwzględnia się przekaz takich wartości jak pokój, sprawiedliwość, niestosowanie przemocy, gospodarowanie, kultura, akceptacja odmienności, a u podstaw wszelkiego działania leży relacja interpersonalna oparta na miłości jako najwyższej wartości, co znajduje swój wyraz w sztuce miłowania, którą proponuje duchowość Chiary Lubich.

Dialog z pracownikami umożliwił wzajemną wymianę głębokich motywacji i wrażeń. Prawie wszyscy wychowawcy tej placówki oprócz dyplomu uniwersyteckiego zdobyli dodatkowe specjalizacje, np.: w muzyce, sztuce, biologii, chemii, naukach o komunikacji, językach słowiańskich, sporcie, co wpływa na urozmaicenie programu kształcenia, a także poszerza możliwości działań interdyscyplinarnych. Atmosfera harmonii i głębokiego zrozumienia panująca w tym miejscu oraz warunki sprzyjające komunii, a także poczucie pracowników, że są na właściwym miejscu, to owoce pozytywnego przeżywania relacji w określonych warunkach pracy.

Wyłaniający się w tym kontekście wzór osobowy wychowawcy to ktoś, kto w „klimacie komunii” i w „stylu pracy” szkoły znalazł dogodną przestrzeń do pełnej realizacji osobistej i zawodowej. To właśnie wpływa na jakość relacji interpersonalnych, a jednocześnie czyni to przedszkole miejscem sprzyjającym harmonijnemu rozwojowi możliwości, jakie ma w sobie każde dziecko. Można było zauważyć, że takie funkcjonowanie tej placówki wychowawczej jest wynikiem dialogu oraz relacji zachodzących pomiędzy różnymi pracownikami i członkami wspólnoty edukacyjnej, która obejmuje wszystkich. Wszyscy są wychowawcami i wszyscy mają świadomość osobistej odpowiedzialności i intencjonalności wychowania: nauczyciele i rodzice, asystenci, kucharze, a także pracownicy administracji. Jest to wspólnota wychowawcza zdolna do angażowania w owocny dialog także środowisko lokalne - miasto, które nie jest przyzwyczajone do budowania relacji interpersonalnych.

Temat seminarium „Dla pedagogiki dialogu” opracowany został przez Giuseppego Milana, który podkreślił, że dialog jest zagadnieniem powszechnie bardzo ważnym, lecz przede wszystkim dla tego, kto działa na polu edukacji. Wychodząc od historii i symboli Słowenii, mistrzowsko omówił 
znaczenie dialogu w dziedzinie pedagogiki, oferując bogate spostrzeżenia teoretyczne i praktyczne: dialog jest typowym sposobem bycia ludzi, kwalifikuje człowieka, definiuje go jako istotę relacyjną. Dialog to słowo, które etymologicznie oznacza poruszanie się pomiędzy; oznacza wejście w relację, nawiązywanie komunikacji, a także pozwala razem planować. Szkoła, mówił Milan, jest właśnie tym miejscem, w którym realizuje się relacyjność i planowanie. Poszukiwanie, pragnienie, odpowiedzialność, zatrzymanie się, projekt, dzielenie się, przebaczenie, pokora to tylko niektóre z filarów, które budują dialog. Dialog jest poszukiwaniem: szukaniem drugiego, widzeniem go w nowy sposób, roz-poznaniem go (głębszym poznaniem go); dialog jest pragnieniem: wymaga spojrzenia ponad; dialog jest uważnym zatrzymaniem się przed drugim; dialog jest odpowiedzialnością; dialog jest programem i dzieleniem się; dialog jest przebaczeniem: zaczynaniem od nowa za każdym razem, by być darem; dialog jest pokorą.

W tych kwestiach (pedagogika dialogu) - potwierdził Milan - otrzymaliśmy i nadal otrzymujemy wspaniałe nauczanie Chiary Lubich, a to jest zasadniczym przedmiotem naszych rozmów, dialogu i planowania. W zakończeniu zacytował fragment jej wykładu, wygłoszonego z okazji otrzymania doktoratu honoris causa $\mathrm{w}$ zakresie pedagogiki (Waszyngton, 2000), w którym podkreśla, że to właśnie dialog jest zasadniczym elementem, nadającym znaczenie działaniu wychowawczemu i umożliwiającym budowanie pomiędzy nami zjednoczonego świata:

„Mimo niezliczonych napięć we współczesnym świecie, nasza planeta, prawie paradoksalnie, zmierza do jedności. Jedność jest znakiem czasów, jest potrzebą czasów [...]. Na każdym polu ludzkiego działania jest więc konieczny proces wychowawczy zgodny z wymaganiami jedności" [...]. Musimy więc realizować pomiędzy nami - kontynuuje Lubich - autentyczniejszą społeczność, gdzie dokonuje się cudowna synteza między pedagogicznymi wymaganiami w zakresie wychowania jednostki a pedagogicznymi wymaganiami z zakresu tworzenia wspólnoty [...]. Naturalnie, nasze doświadczenie życia wspólnotowego ma swoje źródło w zachęcie Jezusa: „Miłujcie się wzajemnie, jak Ja was umiłowałem [...] Bądźcie jedno" (por. J 15,12; 17,21). Jest to motywacja natury religijnej, ale jej skutki na polu wychowania są niezwykłe. Cel, jaki zawsze stawiano wychowaniu (kształtowaniu człowieka, jego autonomii), osiągany jest prawie paradoksalnie poprzez kształtowanie człowieka-relacji ${ }^{3}$.

${ }^{3}$ Chiara Lubich, „Charyzmat jedności i pedagogika. Fragment wykładu wygłoszonego 10 listopada 2000 r. na Catholic University of America w Waszyngtonie, z okazji przyznania 
Po spojrzeniu teoretycznym uwagę skoncentrowano na dialogu pięciu szkół z czterech państw Europy Wschodniej (Chorwacji, Słowenii, Macedonii i Serbii), które po raz pierwszy spotkały się razem, aby podzielić się własnym doświadczeniem pedagogicznym.

Uwydatniono spójność wkładu każdego doświadczenia wychowawczego w lokalny kontekst, z uwzględnieniem jego myśli pedagogicznej, w odpowiedzi na szczególne potrzeby wynikające z uwarunkowań historycznych, społecznych i kulturowych. Przedstawiciele każdej szkoły mogli powiedzieć coś o specyficznych aspektach swojej pracy, takich jak głęboka motywacja, która ożywia szkołę, wybory, które zbliżają tych, którzy pracują w szkole, klimat relacyjny, którym się żyje, kluczowe elementy nauczania, wyzwania, którym trzeba stawić czoła. Poruszono wiele zagadnień, było to doświadczenie ubogacające.

Innym ważnym momentem był dialog pomiędzy naukowcami Giuseppem Milanem a Michelem De Benim, którzy od kilku lat towarzyszą tym szkołom. Wpletli oni, jakby w cennym hafcie, złotą nić podstawowych zasad istotnych dla każdego doświadczenia edukacyjnego: to rozwój życia wewnętrznego dziecka jest priorytetem, a nie dążenie do skuteczności edukacji pojmowanej jako wytwarzanie ,produktów”. Zdaniem tych badaczy dialog jest kluczowym elementem umożliwiającym symetryczną relację pomiędzy wychowawcą a wychowankiem w procesie kształtowania tożsamości, myślenia i refleksji, postrzegania własnych potrzeb i marzeń. Jest to rozwój tego, co UNESCO w 1972 r. zdefiniowało jako „niewidzialny kapitał”. Kryzys edukacyjny tkwi właśnie w nieuznaniu i nieuwidocznieniu tego kapitału. Rozwój dialogu wewnętrznego prowadzi do poszukiwania i odkrycia w człowieczeństwie, które jest w każdym, „dynamicznego my”, które umożliwia rozpoznanie odmienności i rozwinięcie kreatywnego spojrzenia, czyniąc nas zdolnymi do bycia otwartymi na świat. Rozwój tego wewnętrznego życia jest procesem, którego nie przeprowadza się samemu. Jest grą dialogową, która uczy odpowiedzialności i wolności w odkrywaniu działania. Kształcenie dialogowe oznacza rozwój umysłu, serca i rąk w globalnej grze integralnej sztuki wychowania.

Istnieje jednak - podkreślili - „Mistrz”, na którego wszyscy patrzymy i który jest fundamentem naszej zdolności wychowawczej i każdego pro-

Chiarze doktoratu honoris causa z pedagogiki”, w: Chiara Lubich, Charyzmat jedności, red. Michel Vandeleene (Kraków: Fundacja Mariapoli, 2007), 318-319. 
gramu wychowawczego: „Mistrz pomiędzy nami”4. Często Mistrz kryje się w dziecku najbardziej wrażliwym, niepełnosprawnym, imigrancie czy cudzoziemcu. Kruchość w złożoności współżycia międzyludzkiego, współżycia w wymiarze celowości, a przede wszystkim ontologicznym, przyzywa „otwartość” i dialog.

W podsumowaniu podczas dyskusji plenarnej pracownicy szkół ujawnili również niektóre niedociągnięcia i trudności w odpowiednim przełożeniu doświadczenia edukacyjnego na projekty zgodne z propozycją pedagogiczną zrodzoną z duchowości komunii Chiary Lubich. Z pytań i propozycji wynikała potrzeba wzmocnienia dialogu, relacji i dzielenia się różnymi doświadczeniami edukacyjnymi po to, by uwidocznić pedagogię komunii, która jest owocem tego doświadczania w poszczególnych szkołach.

$\mathrm{W}$ oczekiwaniu na opracowanie $\mathrm{w}$ formie naukowej (do zastosowania w procesie nauczania) Michele De Beni zaproponował schemat obserwacji, umożliwiający naukowe opisanie praktycznych działań, obejmujące procesy i ich wyniki możliwe do zastosowania. Dla zespołów wychowawczych działających w różnych szkołach byłaby to okazja do wzbogacenia swoich sposobów interpretacji i analizy działań edukacyjnych w świetle pedagogii komunii. $Z$ takiego punktu widzenia mogliby poznawać zarówno mocne, jak i słabe strony oraz różne kwestie problematyczne w złożonej rzeczywistości kulturalnej i społecznej.

W zakończeniu seminarium uwagę uczestników skierowano ku wspólnemu horyzontowi: to $\mathrm{w}$ pedagogice $\mathrm{w}$ dialogu, która jest owocem miłości wzajemnej, wychowanie będzie mogło odnaleźć swoją istotę. Zrodzi się ono w szkole Jezusa Mistrza, szkole par excellence, uczącej, że miłość jest nie tylko podstawową potrzebą emocjonalną, lecz również kulturową, gdyż umożliwia wzrost i rozwój społeczny.

Ttumaczenie: Stanisław Grochmal, Mariola Teresa Kozubek

${ }^{4}$ W tekstach Chiary Lubich sformułowanie „Mistrz pomiędzy nami” odnosi się do osoby Jezusa Chrystusa [zob.: Chiara Lubich, „Jezus wychowawcą”, w: Chiara Lubich, Charyzmat jedności, red. Michel Vandeleene (Kraków: Fundacja Mariapoli, 2007), 308-313; przypis tłumacza]. 